\title{
Effect of simvastatin in hepatic ischemia and reperfusion in rats
}

\section{Efeito da sinvastatina na isquemia e reperfusão hepática em ratos}

Marília Daniela Ferreira Carvalho, Laís Izabel Maia Melo, Maria Clara Medeiros Chacon, Daniel Costa Rodrigues Farias, Ítalo Medeiros Azevedo, Amália Cínthia Meneses Rêgo, Vítor Brasil Medeiros, Irami Araújo-Filho, Aldo Cunha Medeiros

Research performed at Nucleus for Experimental Surgery, Federal University of Rio Grande do Norte (UFRN), Brazil. Financial support: CNPq, Brazil.

Conflict of interest: none

Correspondence address: Aldo Cunha Medeiros, Department of Surgery, Federal University of Rio Grande do Norte, at Ave. Nilo Peçanha 620, Natal, RN, Brazil, Email: aldo@ufrnet.br

\section{ABSTRACT}

Purpose: Liver injury induced by ischemia and reperfusion is frequently observed in the immediate postoperative period in liver transplantation and partial hepatectomy, when the liver is subjected to a period of partial or total ischemia at various times. The present study aimed to evaluate the effect of simvastatin in preventing liver ischemiareperfusion injury in rats, using the biodistribution of radiopharmaceuticals, biochemical, immunological and histological analysis. Methods: Eighteen Wistar rats were randomly divided into three equal groups of six each. Group sham; Group IR (isquemia of left and medium hepatic lobes for $45 \mathrm{~min}$; reperfusion for $24 \mathrm{hs}$ ); and IR simvastatin group. Animals from IR simvastatin group were treated with simvastatin microemulsion at a dose of $10 \mathrm{mg} / \mathrm{kg}$ v.o. (gavage) once daily for 5 days before ischemia and reperfusion (IR). Results: Both the right and the left hepatic lobe had higher uptake of fitate- ${ }^{99 \mathrm{~m}} \mathrm{TcO}_{4}$ radioactivity in group IR simvastatin than in group IR $(p<0.05)$. The plasma levels of aspartate aminotransferase (AST), alanine aminotransferase (ALT) and lactic dehydrogenase (LDH) were measured at the end of each experiment. Simvastatin pretreatment led to a profound decrease in plasma enzyme levels compared with IR rats $(p \leq 0.001)$. Histopathological examination revealed necrotic areas predominantly in the perivenular zone, cytoplasm vacuolization and sinusoidal congestion in an IR group rats. Simvastatin pretreatment strongly protected livers from these changes. Conclusion: In summary, our study provides the evidence that pretreatment with simvastatin protected rat livers from ischemia/reperfusion injury in vivo. This protective effect was validated by a decrease of plasma liver enzymes and histopathological features of liver injury, as well as by biodistribution of fitate-Tc99m in liver tissue.

Key words: Liver. Ischemia/reperfusion. Simvastatin. Effect. Rats. 


\section{RESUMO}

Objetivo: A lesão hepática induzida por isquemia e reperfusão é freqüentemente observada no período pós-operatório imediato de transplante hepático e hepatectomia parcial, quando o fígado é submetido a um período de isquemia parcial ou total em vários momentos. O presente estudo teve como objetivo avaliar o efeito da sinvastatina na prevenção de lesões por isquemia e reperfusão hepática em ratos, usando a biodistribuição de radiofármacos, dosagem de enzimas hepáticas, e histopatologia. Métodos: Dezoito ratos Wistar foram divididos aleatoriamente em três grupos iguais de seis cada. Grupo sham; Grupo IR (isquemia dos lobos hepáticos esquerdo e médio por $45 \mathrm{~min}$; reperfusão por 24 horas) e grupo IR/sinvastatina. Os animais do grupo IR/ sinvastatina foram tratados com sinvastatina microemulsão numa dose de $10 \mathrm{mg} / \mathrm{kg}$ v.o. (gavagem), uma vez por dia durante 5 dias antes da isquemia e reperfusão (IR). Resultados: os lobos direito e esquerdo tiveram maior captação de radioatividade pelo fitato- ${ }^{-99 \mathrm{~m}} \mathrm{TcO}_{4}$ no grupo $\mathrm{IR} /$ sinvastatina do que no grupo $\mathrm{IR}(\mathrm{p}<0,05)$. Os níveis plasmáticos de aspartato aminotransferase (AST), alanina aminotransferase (ALT) e $(\mathrm{LDH})$ foram medidos no final do experimento. O pré-tratamento com simvastatina levou a uma diminuição nos níveis plasmáticos das enzimas em comparação com os ratos IR $(p \leq 0,001)$. O exame histopatológico revelou áreas necróticas predominantemente na zona perivenular, vacuolização do citoplasma e congestão sinusoidal em ratos do grupo IR. O pré-tratamento com sinvastatina protegeu fortemente o fígado dessas alterações. Conclusão: Em resumo, este estudo forneceu provas de que o pré-tratamento com sinvastatina protegeu o fígado de ratos submetidos a isquemia/reperfusão hepática. $O$ efeito protetor foi validado pela diminuição das enzimas hepáticas, pela redução de lesões histopatológicas no fígado, e pela maior biodistribuição de fitato-Tc99m em tecido hepático.

Descritores: Fígado. Isquemia / reperfusão. Sinvastatina. Efeito. Ratos.

\section{INTRODUCTION}

Liver injury induced by ischemia and reperfusion is frequently observed in the immediate postoperative period in liver transplantation and partial hepatectomy, when the liver is subjected to a period of partial or total ischemia at various times. Much progress has been made in understanding the basic mechanisms of cell injury by hypoxia, considered the main factor involved in ischemia-reperfusion (IR) ${ }^{1}$. Tissue damage occurs during the ischemia phase, and it is significantly augmented in the reperfusion phase ${ }^{2,3}$ 
Various mechanisms have been proposed to explain the mechanisms of ischemia-reperfusion (IR) injury. The implicated factors include free oxygen radicals, leukocyte migration and activation, microcirculatory abnormalities, sinusoidal endothelial cell damage, activation of the coagulation cascade, Kupffer cell activation due to the release of inflammatory cytokines, and proteolytic enzymes ${ }^{4-7}$. After reperfusion, lysosomal lytic enzymes are released into the bloodstream that will cause local and systemic damage, also featuring ischemia and reperfusion. Two distinct phases of activation of the inflammatory occur on the immune system: a first cell acute phase response, which lasts from 1 to 6 hours post-reperfusion, rich in oxygen free radicals and a subacute phase which maintains tissue injury, characterized by release of proinflammatory agents and anti-inflammatories. The major proinflammatory agents are neutrophils followed by cytokines, nitric oxide, endothelin and leukotrienes. These agents can act as important regulators of regional blood flow and metabolic tubular activity, which can be both beneficial or contributing to liver failure ${ }^{8}$.

Statins exert multiple effects on various cells through a number of pathways. These so-called pleiotropic effects are well described in relation to atherosclerosis ${ }^{9-11}$. Data from experimental animal models of sepsis suggest that the pleiotropic mechanisms of statins may beneficially modulate the inflammatory cascades associated with sepsis. Furthermore, observations indicate that statins directly affect the infectivity and proliferation of a diverse array of microorganisms. Although rare randomised controlled trials have tested the efficacy of statins to prevent or treat sepsis, interesting observational data support the hypothesis of a beneficial effect.

Efeitos antiinflamatórios significativos foram demonstrados em infarto do miocárdio de modelos experimentais normocolesterolêmicos, hipercolesterolêmicos e diabéticos, em modelo de isquemia e reperfusão ${ }^{12}$. Nesse aspecto, confere-se um papel relevante aos monócitos ativados na reação inflamatória, que liberam o fator tissular e várias citocinas, dentre elas o fator de necrose tumoral (TNF) e interleucina $6\left(\right.$ IL-6), ditos pró-inflamatórios ${ }^{13}$. As estatinas reduzem os níveis de proteína C-reativa, atenuando a vasculite.

Significant anti-inflammatory effects have been demonstrated in myocardial infarction in experimental normocholesterolemic, hypercholesterolemic models and diabetic model in ischemia and reperfusion ${ }^{12}$. In this aspect, a significant role is atributed to the inflammatory response of activated monocytes, which release tissue factors and various cytokines, among them tumor necrosis factor (TNF) and interleukin 6 (IL-6), known as pro-inflammatory ${ }^{13}$. Statins reduce levels of C-reactive protein, reducing the vasculitis ${ }^{14}$.

The colloid ${ }^{99 \mathrm{~m}} \mathrm{Tc}$-phytate has been widely used to study the liver and spleen ${ }^{15}$, especially for diagnosis and progression of liver disease. However, using this radiocolloid has also been used for biodistribution studies, which is useful for determining parameters of function. Biodistribution to the liver and bone marrow has shown good correlation with the severity of liver diseases such as cirrhosis and fibrosis 
of the organ and its prognosis ${ }^{16}$. Thus, the measurement of the uptake of ${ }^{99 \mathrm{~m}} \mathrm{Tc}$-phytate serves as an excellent index of liver function. The relative distribution of radiopharmaceutical by the liver has been quantified using planar imaging techniques. The ease of quantifying the amount and structure of the liver and the concentration of this radiopharmaceutical by the use of scintigraphy greatly stimulates the use of ${ }^{99 \mathrm{~m}} \mathrm{Tc}$ phytate (colloid) in the liver scintigraphy as a quantitative test of liver function ${ }^{17,18}$.

Based on several experimental studies that have demonstrated that the protective effect of statins on inflammation, ischemia and reperfusion ${ }^{19-21,25}$, the present study aimed to evaluate the effect of simvastatin in preventing liver ischemiareperfusion injury in rats, using the biodistribution of radiopharmaceuticals, biochemical, immunological and histological analysis.

\section{METHODS}

\section{Animals}

We used 18 male Wistar rats from the vivarium of the Health Sciences CenterUFRN. We followed all the precepts of ethics of animal studies provided by Brazilian guidelines and the National Ethics Committee on Animal Research. The animals were randomly selected and divided randomly into three equal groups of six each. Group sham; Group IR, and IR simvastatin group. Animals from IR simvastatin group were treated with simvastatin microemulsion at a dose of $10 \mathrm{mg} / \mathrm{kg}$ v.o. (gavage) once daily for 5 days before ischemia and reperfusion. The animals were anesthetized with an intramuscular injection of $0.1 \mathrm{ml} / 100 \mathrm{~g}$ body weight of a solution consisting of $1.0 \mathrm{ml}$ of ketamine $(50 \mathrm{mg} / \mathrm{ml})$ and $1.0 \mathrm{ml}$ xylazine $(20 \mathrm{mg} / \mathrm{ml})$ as well as intra peritoneal $10 \mathrm{mg} / \mathrm{kg}$ thiopental, operated under asseptic conditions and observed in individual cages. Wather and rat food were permited ad libitum.

In the sham group $(n=6)$ the surgical procedure consisted of a $5 \mathrm{~cm}$ midline incision from the xiphoid, gentle manipulation of the hepatic pedicle and abdominal wall was sutured with nylon $4-0$. In the group $R I(n=6)$ and IR simvastatin group $(n=6)$, hepatic ischemia was induced for 45 minutes by occluding vessels that supply the median and left lateral lobes of the liver using vascular clip (bulldog). During the 45 minutes of ischemia, the abdomen was closed temporarily. After removal of the vascular clamps, the abdominal wall was sutured, occurring reperfusion and observing the animals for 24 hours.

\section{Biodistribution of $\mathrm{Tc}^{99 \mathrm{~m}}$-Fitate}

The biodistribution was examined after 24 hours of IR, to evaluate the response to hepatic ischemia and reperfusion, comparing the right lobe with hepatic lobes subjected to ischemia. After the period of IR, $0.1 \mathrm{ml}$ of phytate-pertechnetate (0.66 
$\mathrm{MBq}$ ) was injected via the femoral vein properly dissected and isolated under anesthesia. After 30 minutes, samples of right and left lobes of the liver were removed, washed in $0.9 \%$ saline solution and weighed on a precision scale (Bel-Engineering-160, Italy). Then the animals were sacrificed by an overdose of anesthesia (thiopental 100 $\mathrm{mg} / \mathrm{kg}$ i.p). The samples were placed in test tubes and introduced in an automatic gamma counter (1470 Wizard, PerkinElmer, Finland) to determine the percentage of radioactivity per gram of liver tissue (\% $\mathrm{ATI} / \mathrm{g})$.

\section{Hematoxylin and Eosin Staining of Liver Sections}

For histologic analysis, defined sections of the ischemic and nonischemic liver were fixed with $10 \%$ buffered formalin $(\mathrm{pH} \mathrm{6.9)}$ and embedded in paraffin. Livers were sliced $(5 \mu \mathrm{m})$ and stained with hematoxylin and eosin. These slices were evaluated for the presence of liver injury by a pathologist who was blinded to the nature of treatment.

\section{Determination of Liver Enzymes}

Blood samples were collected by cardiac puncture at the end of each experiment and immediately centrifuged at $4^{\circ} \mathrm{C}$. Enzyme activities of serum ALT, AST and LDH were determined by standard clinical automated analyses ((Konelab, Software Version, $60 \mathrm{i}$, Espoo, Finland), and the results were expressed in international units per liter. The procedures were performed according to the manufacturer's instructions.

The statistical analysis was performed using the ANOVA and the Tukey and Mann-Whitney tests, considering significant the differences when $p<0.05$.

\section{RESULTS}

Statistical analysis of the experimental results from ischemia and reperfusion under the effect of simvastatin was considered that the animals were randomly divided into three groups of six animals each. Table 1 shows the descriptive results of the percentage of radioactivity per gram of liver tissue (\% ATI/g) found in two lobes of the liver, right and left, as well as tests to investigate the existence of statistically significant differences between the groups sham, IR and IR/Simvastatin. Data analysis of liver function are shown in Table 2. 
Table 1 - Descriptive results and statistical testo of the percentage of radioactivity per gram of liver tissue (\% ATl/g).

\begin{tabular}{|c|c|c|c|c|}
\hline \multirow{2}{*}{ Liver lobe } & \multicolumn{3}{|c|}{$\% A T I / g$} & \multirow{2}{*}{$p$-value ${ }^{(1)}$} \\
\hline & Sham & IR & IR/Simvastatin & \\
\hline Right & $35.46 \pm 4.32$ & $12.56 \pm 2.03$ & $21.99 \pm 3.55$ & 0.048 \\
\hline Left & $36.53 \pm 5.03$ & $6.93 \pm 1.42$ & $14.18 \pm 3.13$ & 0.035 \\
\hline$P$-value ${ }^{(2)}$ & 0.855 & 0.005 & 0.041 & \\
\hline
\end{tabular}

Mean \pm Standard deviation

1. P-value of analysis by $t$ test for independent samples comparing treatments.

2. P-value of analysis by $t$ test for dependent samples comparing the right and left lobes.

It is observed in Table 1 that both the right and the left lobe had higher uptake of radioactivity in group that made use of simvastatin $(p<0.05)$. When comparing the hepatic lobes of the same group of animals, it was observed that in the IR group, the left lobe - that suffered ischemia - showed a lower uptake of radiotracer $(p=0.005)$, when compared with the right lobe. In the group treated with simvastatin (IR/simvastatin) there was a reduction of radioactivity in the left ischemic lobe and the difference was statistically significant $(p=0.041)$. Between the right and left lobes of the sham group we did not detect a significant difference $(p=0.855)$.

Table 2 - Descriptive results and statistical test about the hepatic enzymes.

\begin{tabular}{l|ccc|c}
\hline \multirow{2}{*}{$\begin{array}{c}\text { Biochemical } \\
\text { parameters }\end{array}$} & \multicolumn{3}{|c|}{ Group } & \multirow{2}{*}{ p-value ${ }^{(1)}$} \\
\cline { 2 - 3 } AST $(\mathrm{U} / \mathrm{L})$ & Sham & $\mathrm{IR}$ & $\mathrm{IR} /$ Simvastatin & \\
$\mathrm{ALT}(\mathrm{U} / \mathrm{L})$ & $7.43 \pm 1.34$ & $28.60 \pm 5.03$ & $10.83 \pm 2.14$ & 0.001 \\
$\mathrm{LDH}(\mathrm{U} / \mathrm{L})$ & $11.73 \pm 1.64$ & $34.80 \pm 6.69$ & $15.67 \pm 2.94$ & $<0.001$ \\
\hline
\end{tabular}

Mean \pm Standard deviation

1. P-value of analysis of $t$ test for independent samples.

The plasma levels of aspartate aminotransferase (AST), alanine aminotransferase (ALT) and lactic dehydrogenase (LDH) were measured at the end of each experiment. As shown in table 2, simvastatin pretreatment led to a profound decrease in plasma enzyme levels compared with IR rats $(p \leq 0.001)$. 


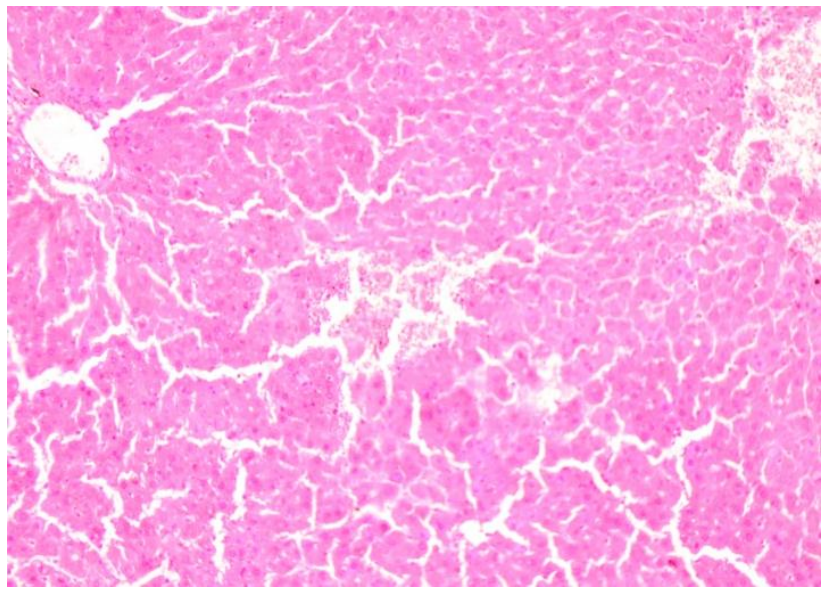

Figure 1 - Sinusoids congestion, focal areas of necrosis in left lobe of IR group rat. HE 200x

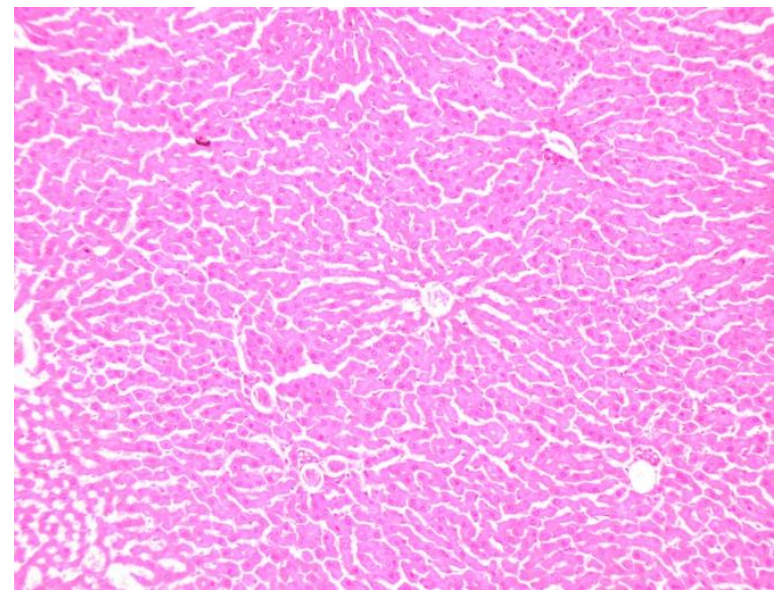

Figure 2 - Minor congestion. Left lobe of IR simvastatin group rat. HE 200x

Histopathological examination revealed necrotic areas predominantly in the perivenular zone, cytoplasm vacuolization and sinusoidal congestion in an IR group rats (Fig. 1). Simvastatin pretreatment strongly protected livers from these changes (Fig. 2).

\section{DISCUSSION}

Enzymes such as ALT, AST, and LDH are used as markers of cellular damage following hepatic IR injury. In various studies, it has been shown that the serum concentrations of these enzymes increase in proportion with the duration of ischemia. The levels persist for some period during reperfusion and then return to normal levels ${ }^{22}$. In our study, it was demonstrated that the serum AST, ALT, and LDH levels of the $\mathrm{IR} /$ simvastatin group were significantly lower than those of the IR alone group and were nearer the normal range. This suggests that simvastatin decreases hepatic cellular damage. These effects of simvastatin after IR injury may be due to protection of sinusoidal endothelial cells, which are the first target. Light microscopic studies showed that 30 and 45 min of hepatic ischemia followed by reperfusion is not associated with marked changes ${ }^{23}$. In contrast, 60 min of ischemia followed by reperfusion may cause tissue damage, and even necrosis ${ }^{24}$. In our study, $45 \mathrm{~min}$ of ischemia followed by $24 \mathrm{~h}$ of reperfusion caused sinusoidal congestion and cytoplasmic vacuolization in midzonal areas. The changes were less marked in the IR/simvastatin group. These results sugest that the beneficial effects of simvastatin on hepatic IR injury may be at the cellular level. So, simvastatin pretreatment decreased liver damage, according to both morphological and functional criteria, in this experimental IR model in rats, even though its detailed mechanism of action remains unclear. Further experimental and clinical studies on the protective role of simvastatin IR injury may contribute to increasing the safety of portal pedicle clamping. 
Our laboratory has previously demonstrated that administration of simvastatin differentially induces intestinal protection in rats subjected to bowel ischemia/reperfusion, diabetes and sepsis ${ }^{19,25}$. We could show that treatment with simvastatin enhances inflammatory reaction after intestine ischemia/reperfusion (I/R). Based on these results obtained under controled conditions, we performed the present study to evaluate the influence of simvastatin on hepatocellular integrity after warm IR. Our results provide the first evidence that pretreatment with simvastatin protects rat livers from IR injury. Hepatic organ protection was indicated by a decrease in plasma liver enzymes (ALT, AST, and HDL) and reduced histopathological features of liver damage. We could detect significant changes in biodistribution of fitate-Tc ${ }^{99 m}$ among the different groups, and hepatic uptake tended to be higher in simvastatin treated animals after ischemia/reperfusion. This overall protective effect was significant.

The pathophysiology of hepatic IR injury is characterized by an interplay of mainly 3 key mechanisms, including microcirculatory disturbances, the initiation of an inflammatory response, and the generation of reactive oxygen species ${ }^{26}$. The maintenance of microvascular perfusion after hepatic ischemia plays a crucial role in the prevention of liver cell injury. As shown by others, early restoration of liver blood flow after ischemia is of particular importance to prevent hepatocellular death ${ }^{27}$.

A cohort analysed data from 438 patients requiring hospitalisation for an episode of bacteraemia between 2000 and 2003. Mortality was significantly reduced in patients receiving statins at the time of hospitalization, and the higher reduction in mortality was observed in patients who continued to receive a statin after the diagnosis of bacteraemia. This study provides the evidence pointing to a potential treatment benefit of statin in septic human patients ${ }^{28}$. A number of animal models of sepsis provide data supporting the notion that statins may be effective in the prevention of sepsis. Mice rendered septic while receiving simvastatin survived four times longer than controls, while cardiac and haemodynamic function was completely preserved ${ }^{29}$. Furthermore, mice receiving statin before lipopolysaccharide injection expressed significantly reduced serum levels of tissue necrosis factor-alpha and interleukin1-beta at 2 hours. These changes translated into a survival benefit with 7-day survival rates significantly improved in treated mice ${ }^{30}$. These data corroborates the findings of our study.

In summary, our study provides the evidence that pretreatment with simvastatin protects rat livers from ischemia/reperfusion injury in vivo. This protective effect was validated by a decrease of plasma liver enzymes and histopathological features of liver injury, as well as by biodistribution of fitate-Tc99m in liver tissue. Our results reveal a potential therapy against hepatic IR injury. Further studies are required to confirm these effects. 
Effect of simvastatin in hepatic ischemia and reperfusion in rats

Carvalho MDF, et al

\section{REFERENCES}

1. Hossain MA, Izuishi $\mathrm{K}$, Maeta $\mathrm{H}$. Protective effects of $\mathrm{d}$-allose against ischemia reperfusion injury of the rat liver. J Hepatobiliary Pancreat Surg. 2003;10:218-25.

2. Clavien PA. Sinusoidal endothelial injury during hepatic preservation and reperfusion. Hepatology. 1998;28:281-5.

3. Inglott FR, Habib NA, Mathie RT. Hepatic ischemia-reperfusion injury. Am J Surg. 2001;181:160-6.

4. Giakoustidis D, Papageorgiou G, Iliadis S, et al. Intramuscular administration of very high dose of alpha tocopherol protects liver from severe ischemia/reperfusion injury. World $\mathrm{J}$ Surg. 2002;26:872-6.

5. Suzuki S, Toledo-Pereyra LH. Interleukin 1 and tumor necrosis factor production as the initial stimulants of liver ischemia and injury. J Surg Res. 1994;57:253-8.

6. Shibuya H, Ohkohchi N, Tsukomato S. Tumor necrosis factor induced, superoxidemediated neutrophil accumulation in cold ischemic/reperfusion rat liver. Hepatology. 1997;26:113-20.

7. Palma-Vargas JM, Toledo-Pereyra LH, Dean RE, et al. Small molecule selectin inhibitor protects against liver inflammatory response after ischemia and reperfusion. J Am Coll Surg. 1997;185:365-72.

8. Abu-Amara M, Yang SY, Tapuria N, Fuller B, Davidson B, Seifalian A. Liver ischemia/reperfusion injury: processes in inflammatory networks. Liver Transpl. 2010;16:1016-32.

9. Marz W, Koenig W. HMG-CoA reductase inhibition: antiinflammatory effects beyond lipid lowering? J Cardiovasc Risk. 2003;10:169-79.

10. Weitz-Schmidt G. Statins as anti-infl ammatory agents. Trends Pharmacol Sci. 2002; 23:482-86.

11. Shovman O, Levy Y, Gilburd B, Shoenfeld Y. Antiinfl ammatory and immunomodulatory properties of statins. Immunol Res. 2002; 25:271-85.

12. Cotterill, L.A.; Gower, J.D.; Fuller, B.J.; Green, C.J. Evidence that calcium mediates free radical damage through activation of phospholipase $A 2$ during cold storage of the rabbit kidney. Adv Exp Med Biol. 1990; 264:397-400.

13. Doctor, R.B.; Mandel, L.J. Minimal role of xanthine oxidade and oxygen free radicals in rat renal tubular reoxygenation injury. J Am Soc Nephrol. 1991; 7:959-69

14. Endo A, Kuroda M. Citrinin, an inhibitor of cholesterol synthesis. J Antibiot. 1976;29: 841-3.

15. Huet PM, Chartrand R, Marleau D. Extrahepatic uptake of Tc-99m-phytate: its mechanism and significance in chronic liver disease. Gastroenterology. 1980, 78:76-80.

16. Hoefs JC, Wang F, Kanel G. Functional measurement of hepatic mass in cirrhotic nonfibrotic pacientes. Am J Gastroenterol. 1997, 92:2054-8.

17. Hoefs JC, Wang F, G Kanel , P. Braunstein The liver-spleen scan as a quantitative liver function test: correlation with liver severity at peritoneoscopy. Hepatology. 1995, 22:111321.

18. Strauss LG, Clorius JH, Frank T, G. Van Kaick Single photon emission computerized tomography (SPECT) for Estimates of liver and spleen volume. J Nucl Med. 1984; 25:81-5.

19. Araújo-Filho I, Jácome DT, Rêgo AC, Azevedo IM, Egito ES, Medeiros AC. Effect of the simvastatin in abdominal sepsis of diabetic rats. Rev Col Bras Cir. 2010;37:39-44.

20. Dantas AC, Batista-Júnior FF, Macedo LF, Mendes MN, Azevedo IM, Medeiros AC. Protective effect of simvastatin in the cyclophosphamide-induced hemorrhagic cystitis in rats. Acta Cir Bras. 2010;25:43-6. 
21. Rego AC, Araújo Filho I, Damasceno BP, Egito ES, Silveira IA, Brandão-Neto J, Medeiros AC. Simvastatin improves the healing of infected skin wounds of rats. Acta Cir Bras. 2007;22 (Suppl 1):57-63.

22. Usami M, Furuchi K, Shiroiwa $\mathrm{H}$, et al. Effect of repeated portal triad cross-clamping during partial hepatectomy on hepatic regeneration in normal and cirrhotic rats. J Surg Res. 1994;57:541-8.

23. Nakano H, Kuzume M, Namatame K, et al. Efficacy of intraportal injection of anti-ICAM-I monoclonal antibody against liver cell injury following warm ischemia in the rat. Am J Surg. 1995;170:64-6.

24. Stein HJ, Oosthuizen NMJ, Hinder RA, et al. Oxygen free radicals and glutathione in hepatic ischemia-reperfusion injury. J Surg Res. 1991;50:398-402.

25. Azevedo, IM, Rego A C M, Medeiros V B, Carvalho MDF, Egito EST, Medeiros A C. Bacterial translocation in rats treated with simvastatin undergoing intestinal ischemia and reperfusion. J Surg Cl Res. 2010:1:54-65.

26. Jaeschke $H$. Molecular mechanisms of hepatic ischemia-reperfusion injury and preconditioning. Am J Physiol Gastrointest Liver Physiol. 2003;284:G15-G26.

27. Chun K, Zhang J, Biewer J, et al. Microcirculatory failure determines lethal hepatocyte injury in ischemic/reperfused rat livers. Shock. 1994;1:3-9.

28. Kruger P, Fitzsimmons K, Cook D, Jones M, Nimmo G. Statin therapy is associated with fewer deaths in patients with bacteraemia. Intensive Care Med. 2006; 32: 75-79.

29. Merx MW, Liehn EA, Janssens U, et al. HMG-CoA reductase inhibitor simvastatin profoundly improves survival in a murine model of sepsis. Circulation 2004; 109: 2560-5.

30. Ando H, Takamura T, Ota T, Nagai Y, Kobayashi K. Cerivastatin improves survival of mice with lipopolysaccharide-induced sepsis. J Pharmacol Exp Ther. 2000; 294: 1043-46. 